\title{
相対論的電子ビーム（REB）直接励起レーザー研究用 光学セルの試作
}

\author{
秋津 哲也 金井 久 $^{*}$ 高塚 正行 $^{* *}$ 松沢 秀典 \\ (山梨大学工学部電気工学科)
}

(1984年12月 3 日 受理)

\section{Construction of the Optical Cell for the REB Excited Laser Experiment}

\author{
Tetsuya Akitsu, Hisashi Kanai ${ }^{*}$, Masayuki Takatsuka ** \\ and Hidenori Matsuzawa
}

\begin{abstract}
An optical cell was constructed for the comparative study of the excitation characteristics of the laser medium between the REB (Relativistic Electron Beam) and the transverse discharge.
\end{abstract}

\section{1.はじめに}

電子ビームはレーザー媒質の直接励起用や放電レーザーの放電制御用等のレーザー開発の分野において広く 研究開発や利用が行なわれている。このような電子ビームの゙励起特性を向上させ, 高出力化を図る場合に, 電 子ビームの高気圧ガス中の伝搬特性, 励起空間内での均一度, 電子ビームによって媒質内に与えられた励起工 ネルギーの空間分布やエネルギー移行の過程などを知ることが必要である。電子ビーム直接励起レーザーの場 合にはその空間分布はレーザー媒質の励起の空間的均一性やレーザーの効率に直接結び付くからである。我々 はこのような点を調べることを目的として, 同軸マルクス型相対論的電子ビーム (REB) 発生器を製作し，こ れによって Ar-N 2 混合気体や Ar 中に拡散された Mn 等に REB を照射し, 励起・発光特性抢よび高気圧 の希ガス中を伝搬する電子ビームの空間分布を測定した。

電子ビーム直接励起型 $\mathrm{Ar}-\mathrm{N}_{2}$ レーザーやエキサイマー・レーザーがよく知られている。これらと並んで 高利得, 高出力の新型レーザーとなる可能性がある金属蒸気レーザーの場合には, 発振に必要な蒸気密度を得

Department of Electrical Engineering, Faculty of Engineering, Yamanashi University.

* 東芝 $\quad *$ Toshiba **石川島建機 ** Ishikawajima-Construction Machinary 
るために，媒質を高温に加熱する必要があるが，低い加熱温度で動作する金属蒸気レーザーが実現すればその 実用上の価值が高くなるものと考えられる。この問題点の解決方法として, 比較的常温に近い温度で適当な蒸 気圧を有する金属化合物を用いて，これを放電領域内で解離させ，得られた金属原子を励起することによって 発振の可能性の実験的検討が行なわれている。

Mnレーザーの場合, $534.1 \mathrm{~nm}$ で, $37 \mathrm{~dB} / \mathrm{m}$ の高利得のレーザー発振が観測されているが, 金属 $\mathrm{Mn}$ か ら蒸気を発生する為には, 媒質を $1060^{\circ} \mathrm{C}$ の高温度に加熱する必要がある。 ${ }^{(1)}$ 化合物の場合には, $680^{\circ} \mathrm{C}$ に加熱した塩化マンガン蒸気中で, 連続したパルス放電によって解離と反転準位の生成を行なう Double Pulse 法で励起された分解生成物の Mn のレーザー発振が観測されている。 ${ }^{(2)}$

本報告では，常温において液体でありしかも高い蒸気圧を有する，有機 $\mathrm{Mn}$ 化合物 $\mathrm{CH}_{3} \mathrm{C}_{5} \mathrm{H}_{4} \mathrm{Mn}(\mathrm{CO})_{3}$ ; Methylcyclopentadienyl-Manganese Tricarbonyl，の蒸気を Ar または He 中に拡散して，REBの照射に よる励起と, 緩衝気体中の横方向アーク放電による励起の 2 種類の方法を用いて励起した Mn の励起状態を分 光測定を用いて調べ，これらの励起方法を比較検討する。

\section{2. 実験装置}

Fig. 1 に電子ビームの発生に用いた相対論的電子ビーム発生装置 YES-2 の概念困を示す。この装置は同 軸マルクス・バンクであり, 低インダクタンス型セラミック・キャパシターを直並列接続した 4 個のモジュー ルによって構成されている。各モジュールは最大 $\pm 60 \mathrm{kV}$ の両極性電源によって充電され, 全体で $480 \mathrm{kV}$ の負極性高電圧パルスを発生する。YES-2 の諸特性は下記の表に示されている。

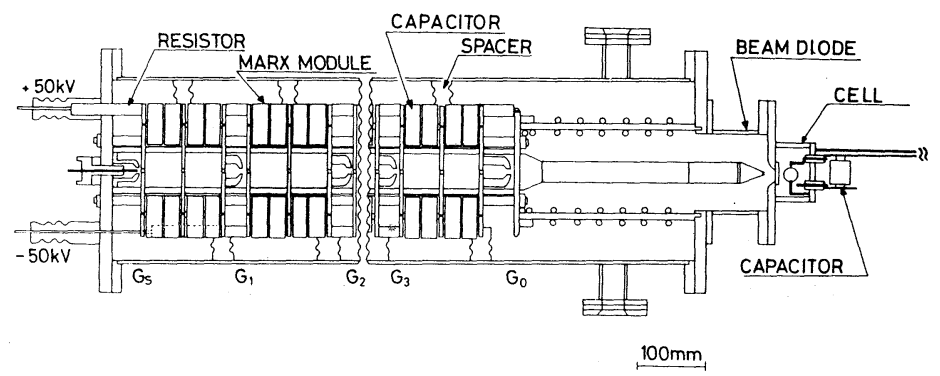

Fig. I. 同軸型マルクス発性器, YES - II

The coaxial Marx generator, YES II

Fig. 2 にビーム・ダイオード部の構造 が 示されている。この部分では絶縁油と真空の 境界面をなすアクリル管の沿面放電による破 壊を避けるために, アクリル管の内外に沿面 距離を長くするための溝を設計し，さらに銅 パイプ製均圧環を等間隔で固定し，陽極一陰 極間の電圧を静電分圧して, 電界の集中を防 いでいる。 ${ }^{(3)},(4)$
表 1 同軸マルクス型相対論的電子ビーム (REB) 発生器 YES - 2

\begin{tabular}{|l|l|}
\hline 最大充電電圧 & $60 \mathrm{kV}$ 両極性充電 \\
段数 & 4 \\
無負荷出力電圧 & $480 \mathrm{kV}$ \\
最大蓄積エネルギー & $117 \mathrm{~J}$ \\
構成ユニッ & $5 r T O_{3}$ キャパシター, \\
& 静電容量 $2700 \mathrm{pF}$, \\
& $30 \mathrm{kV}$ 直列接続 \\
ユニット数 & 96 \\
総合容量 & $1012.5 \mathrm{pF}$ \\
絶縁方式及び容積 & 油入絶縁 \\
& 直径 $350 \mathrm{~mm}$ \\
& 長さ $974 \mathrm{~mm}$ \\
\hline
\end{tabular}




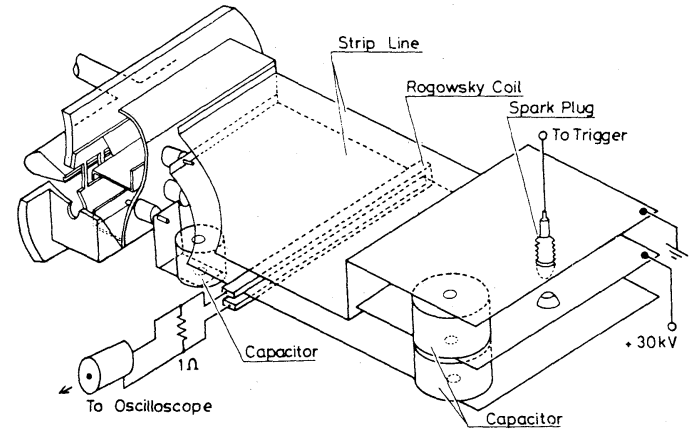

Fig. 2. 実験装置, 相対論的電子ビーム発生用陰極, Hibachi 構造の陽極, 蒸気セル,レール電極お よび放電回路。

Experimental setup. The graphite cathode, the multi-grid structure and $30 \mu \mathrm{m} \mathrm{Ti}$ foil anode, the vapor cell, the rail electrodes and the strip line of the discharge circuit are shown.

マルクス発生器の出力電圧は, 直径 $30 \mathrm{~mm}$ のジュラルミン製の伝送線路に沿って真 空中をビーム照射部の陰極に伝達される。 陰極は優れた電界放出特性を有するグラ ファイト製であり，横幅 $150 \mathrm{~mm}$ の偏平 な形状をしている。電子ビームは, 厚さ $30 \mu \mathrm{m}$ のチタン䇴の陽極を通過し, 実験 領域内の気体を励起する。1-5 気圧の 実験領域の圧力を支持するためにチタン 䈌は幅 $1.5 \mathrm{~mm}$ のグリッドによって支え られ, 光軸に平行方向が $6 \mathrm{~mm}$, 垂直方 向が $10 \mathrm{~mm}$ 幅の 21 個の開口部に分割さ れている。電子ビームがこの部分を通過 する際に不均一性を生じるが，緩衝気体 中を伝搬するに従って散乱されて再び均 一化される。

実験領域の蒸気七ルは資料気体の励起領域の長さが $210 \mathrm{~mm}$, 容積 $630 \mathrm{~cm}^{3}$ であり, 陽極から $20 \mathrm{~mm}$ の 位置の光軸の両端に直径 $10 \mathrm{~mm}$ の石英製の光学悹が備えられている。さらに，光軸に沿って，長さ $150 \mathrm{~mm}$ の $\mathrm{A} 1$ 製レール電極が $11 \mathrm{~mm}$ 間隔で設置されており，放電励起による気体の発光も観察できる。この放電回 路が Fig. 3 に示されている。この回路には予備放電回路および電極が設けられており，主放電に先だって予 備電離を行なって放電媒質を電離させた後に、レール電極全体に均一な主放電が開始される。

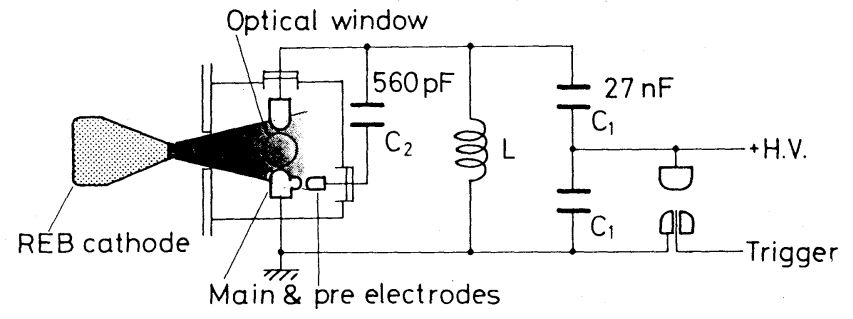

Fig. 3. 放電回路の等価回路

The schematic diagram of the discharge circuit

\section{3. 実験結果および考察}

\section{1 REB の空間分布}

REB による媒質励起の空間的な均一製について検討するため, 照射線量によって呈色が変化する Radcolor Film ${ }^{(5)}$ を用いて，緩衝気体中を伝搬する REB の線量分布を測定した。Fig. 4 は REBのエネルギーが 


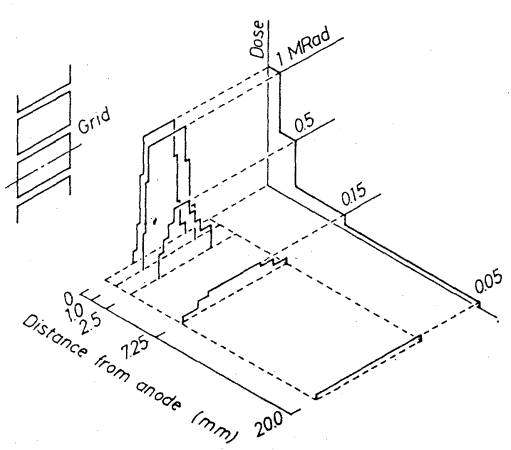

(a) 縦方向分布

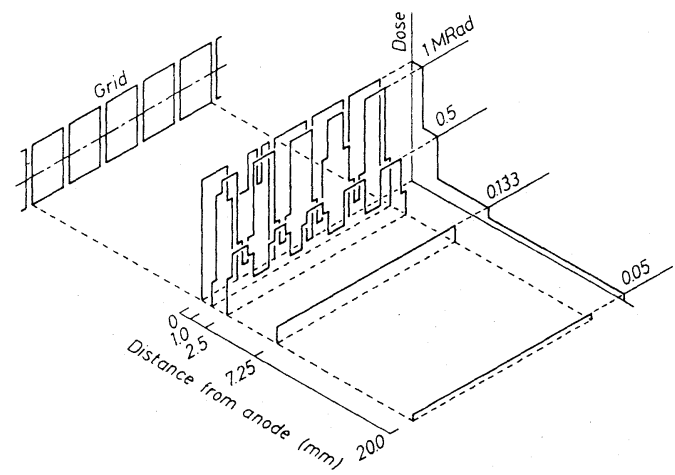

(b) 軸方向 分 布

Fig. 4. 陽極から, $Z=0$, I., 2.5, 7.25, $20 \mathrm{~mm}$ の位置における REB のビームエネルギー, $360 \mathrm{keV}$, 緩衙気体, Ar 3 気压。

The distribution of REB dose, a : perpendicular and, b : parallel to the opitical axis, at $z=0$., I., 2.5, 7.25 and $20 \mathrm{~mm}$ from the anode, beam energy, $360 \mathrm{keV}$, buffer gas, Ar, $3 \mathrm{~atm}$.

$360 \mathrm{keV}$ ，緩衝気体は 3 気圧の Ar の場合に，ビームの伝搬方向に陽極から，0，2.5，7.25，および $20 \mathrm{~mm}$ の位置に Radcolor Film をグラファイト製のブロックを用いて固定し，その変色の度合から REB 1 ショット当たりでの線量分布を測定した。Fig. 4(a) は光軸に対して垂直方向に $20 \mathrm{~mm}$ の線量分布，同図(b) は光軸に平行方向に $40 \mathrm{~mm}$, すなわち 5 グリッド分の蒸気セル中心部の線量分布を示している。光軸は陽極 より $20 \mathrm{~mm}$ の距離の所にあるが，陽極から $7.25 \mathrm{~mm}$ の 位置においてビームの線量分布は均一性が得られている。

Fig. 5 は陽極表面における平均值で規格化された電子ビ 一ムの強度の伝搬距離にたいする依存性を示し, 電子ビー ムが伝搬によって散乱あるいはエネルギー吸収を受け減衰 する様子を示している。

Fig. 6 には, ビームのエネルギーが $400 \mathrm{keV}$ の場合の, 陽極表面および光軸上の蒸気セル全長にわたる線量分布が 示されている。このように，陽極通過直後の電子ビームは 数多くの非常に局在したフィラメント状の分布を示すこと が有るが，このような微細構造は， REB が緩衝気体によ って散乱されて速やかに消滅し, 光軸上では 1 ショット当 たり $0.05 \mathrm{M} \mathrm{rad}$ の照射線量に相当する REB による媒質 の均一な励起が実現しているものと考えられる。

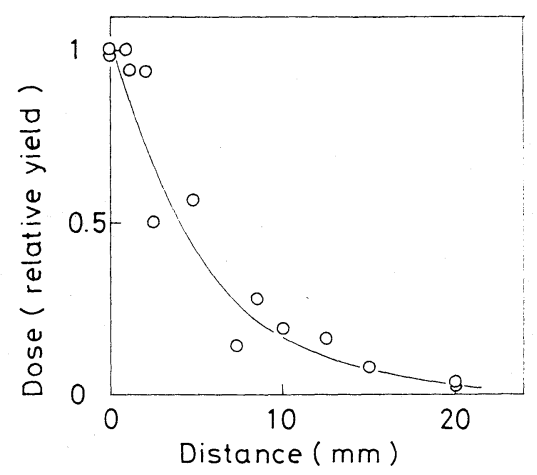

Fig. 5. REB の照射線量の伝搬方向の分布。 The variation of the REB intensity with with the distance from the anode surface. 

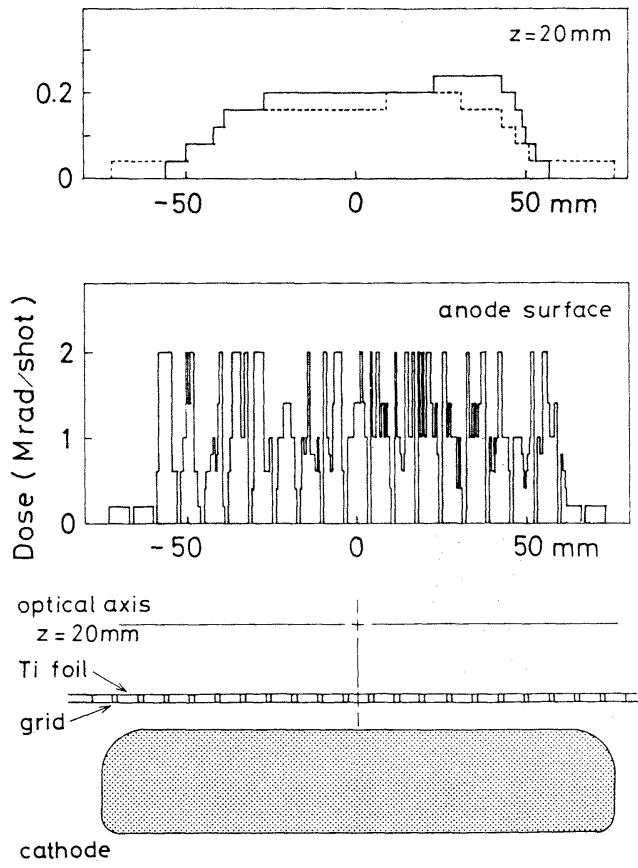

Fig. 6. 陽極表面と光軸上 ( $z=20 \mathrm{~mm}$ ) の REB の 照射線量分布, ビーム・エネルギー, $400 \mathrm{keV}$, 緩衝気体, $\mathrm{Ar}, 3$ 気圧。

The distribution of REB at the surface of the anode and $z=20 \mathrm{~mm}$, at the optical axis, beam energy, $400 \mathrm{keV}$, buffer gas, Ar, $3 \mathrm{~atm}$.

\section{2 REB 励起 $\mathrm{N}_{2}$ の発光特性}

エネルギー移行型レーザーである $\mathrm{Ar}-\mathrm{N}_{2}$ レーザーの励起特性は S. K. Searles ${ }^{(6),(7)}$ や W. E. Ernst ${ }^{(8)}$ に よって研究され，その特性が良く知られている。これらの実験結果との比較のため, この装置を用いて $\mathrm{Ar} 一$ $\mathrm{N}_{2}$ 混合気体を REB 励起し， $\mathrm{N}_{2}$ レーザーの発振が観測されている $(336.5,337.1,357.6 \mathrm{~nm})$ の発光特 性を観察した。

Fig. 7(a)には REB 励起による $\mathrm{N}_{2}$ の発光スペクトルが示されている。同図(b)には室素の圧力が 3 気圧の 場合の REB 電流と $337.1 \mathrm{~nm}$ の発光強度の時間変化が示されている。これらのスペクトルの発光強度の $\mathrm{N}_{2}$ の圧力に対する依存性が Fig. 8 に示されている。いずれの波長においても発光強度は $\mathrm{N}_{2}$ の圧力の増加に伴 って強くなり，飽和する傾向を示した。

次に, 緩衝気体の原子の準安定状態の励起隼位からのエネルギー移行による励起の効果を調べるために, 緩 衝気体として $\mathrm{Ar}$ を用い，全圧力を 3 気圧とし， $\mathrm{N}_{2}$ の分圧比を変えて，各ラインの発光特性を調べた。

Fig. 9 に各ラインの発光強度の $\mathrm{N}_{2}$ 分圧比に対する依存性が示されている。 $\mathrm{N}_{2}$ の圧力が全体の $5 \%$ とき

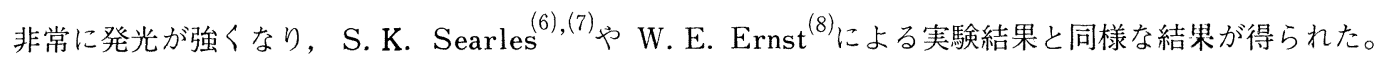




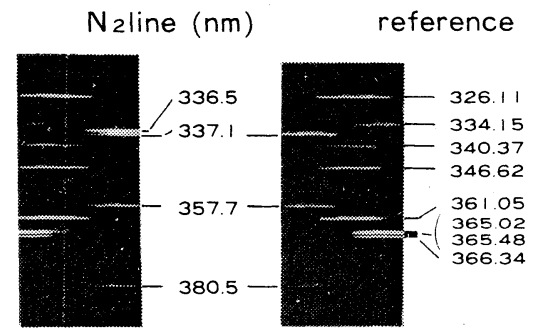

$\mathrm{N}_{2} 3 \mathrm{~atm}$.

7.5 Torr

(a)

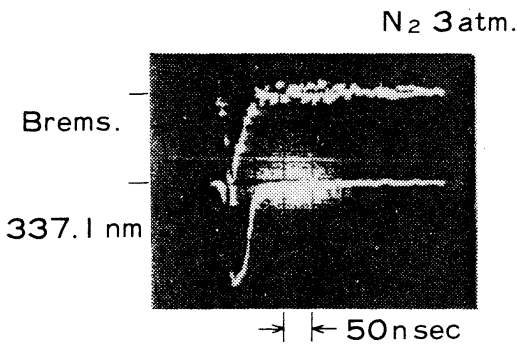

(b)

Fig. 7. REB 励起された, $\mathrm{N}_{2}$ の発光スペクトル, REB の電流波形 (Bremsstrahlung によるX線信号) お よび $\mathrm{N}_{2}$ の発光強度の時間変化。

The emission spectrum for pure $\mathrm{N}_{2}$ excited by REB, and the time evolution of the REB pulse (the Bremsstrahlung $X$-ray signal) and the spectral emission of nitrogen.

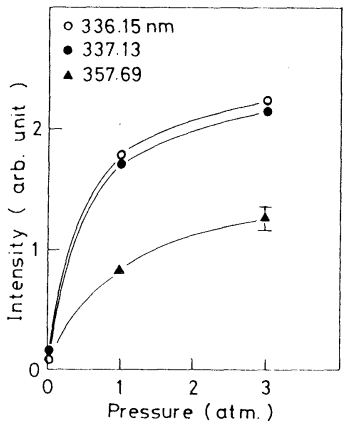

Fig. 8. REB 励起された, $\mathrm{N}_{2}$ からの $337.13 \mathrm{~nm}$, $336.15 \mathrm{~nm}, 357.69 \mathrm{~nm}$ の発光強度の圧力依存性。 The pressure dependense of the spectral emission from pure nitrogen excited by REB.

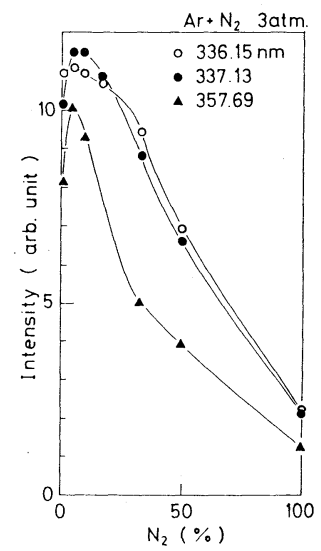

Fig. 9. REB 励起された $\mathrm{Ar}-\mathrm{N}_{2}$ 混合気体からの $\mathrm{N}_{2}$ の発光 強度の分圧比依存性。

Variation of the intensity of the spectral emission of nitrogen with the fractional $\mathrm{N}_{2}$ partial pressure for $\mathrm{Ar}-$ $\mathrm{N}_{2}$ mixture. 
従って, 直接励起以外に次のようなエネルギー移行過程が生じているものと考えられる。

$$
\begin{aligned}
& \mathrm{Ar}+\mathrm{e}^{*} \rightarrow \mathrm{Ar}^{+}+\mathrm{e}+\mathrm{e} \\
& \mathrm{Ar}^{+}+2 \mathrm{Ar} \rightarrow \mathrm{Ar}_{2}^{+}+\mathrm{Ar} \\
& \mathrm{Ar}_{2}^{+}+\mathrm{e} \rightarrow \mathrm{Ar}+\mathrm{Ar} \\
& \mathrm{Ar}^{*}+\mathrm{N}_{2} \rightarrow \mathrm{Ar}+\mathrm{N}_{2}^{*}\left(\mathrm{C}^{3} \pi \mathrm{u}\right) ; \text { エネルギー移行過程 } \\
& \mathrm{N}_{2}^{*}\left(\mathrm{C}^{3} \pi \mathrm{u}\right) \rightarrow \mathrm{N}_{2}\left(\mathrm{~B}^{3} \pi \mathrm{g}\right)+\mathrm{h} \nu
\end{aligned}
$$

$\mathrm{Ar}-\mathrm{N}_{2}$ エネルギー移行レーザーは $\mathrm{Ar}^{*}(4 \mathrm{~s})$ から $\mathrm{N}_{2}$ の $\mathrm{C}^{3} \pi \mathrm{u} へ$ へエネルギー移行によってこの状態が 選択的に励起されることによるものである。

以上の実験によって Ar の準安定の励起状態が REB 励起によって生じていることが示された。金属蒸気 レーザーの場合には, 常温付近では高い飽和蒸気圧が得られず, 従って REB に対する充分な阻止能が単独で は得られないため，このような緩衝気体の準安定状態の励起準位からのエネルギー移行効果を用いることによ って, REB による Lasant の直接励起のみの場合よりも非常に効率の良い励起が可能になる。

\section{3 REB 励起 Mn 化合物の発光特性}

有機金属化合物 $\mathrm{CH}_{3} \mathrm{C}_{5} \mathrm{H}_{4} \mathrm{Mn}(\mathrm{CO})_{3} ;$ Methylcyclopentadienyl-Manganese Tricarbonyl, の蒸気を， $\mathrm{Ar}$ または $\mathrm{He}$ の緩衝気体中に拡散し， REB 励起による発光特性を調べた。

Fig. 10 は有機マンガン化合物を 3 気圧の $\mathrm{Ar}$ または $\mathrm{He}$ の緩衝気体中で REB 励起 (ビーム・ エネルギー $400 \mathrm{keV}$, ) を行った場合の発光スペク トルを示している。この実験の結果から，このよ うな有機化合物を使用しても Mn のスペクトルの みが強く発光し，他の原子や， $\mathrm{C}_{2}$ 等の分子的な 発光は観測されないことが明らかになった。

Fig. 11 は Mnの比較的発光強度の強いライン の発光強度の時間的変化を示している。これらの 波形を比較すると， 2 価の Mn イオンの発光は電 子ビーム大射とほぼ同時に立ち上がるが，1価の イオンはやや遅れ，中性の Mn の発光はさらに遅 れて，ほとんど電子ビームの照射が終ってから， ゆっくりと立ち上がっている。REB 照射と同時 に，有機 Mn 化合物は完全に解離され，Mnは高 いイオン化状態に励起されているものと考えられ る。1 価のイオンや中性の Mn 等の低エネルギー の準位は上のエネルギー準位からの緩和や, 励起

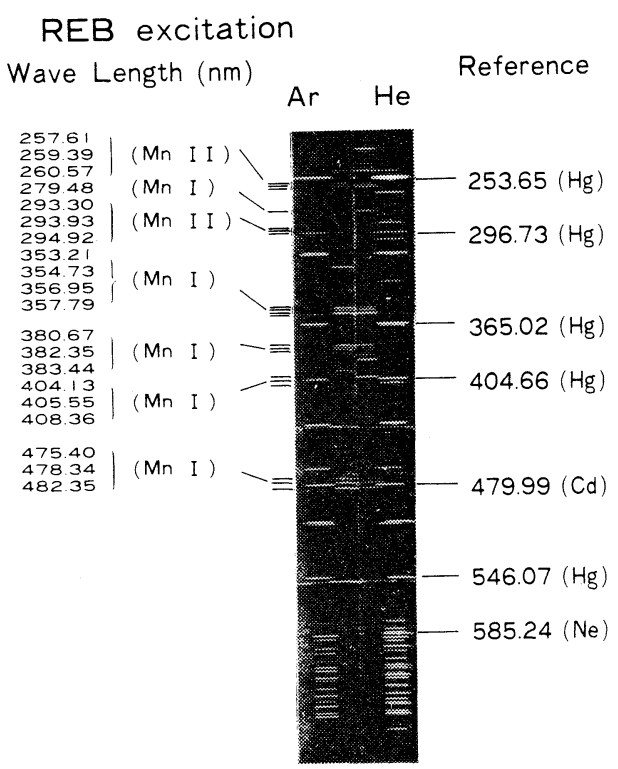

Fig. 10. REB 励起された緩衝気体中の Mn 化合物 からの発光スペクトル。 The emission spectrum for $M n$ diffused in the buffer gas excited by REB. 


\section{REB excitation}

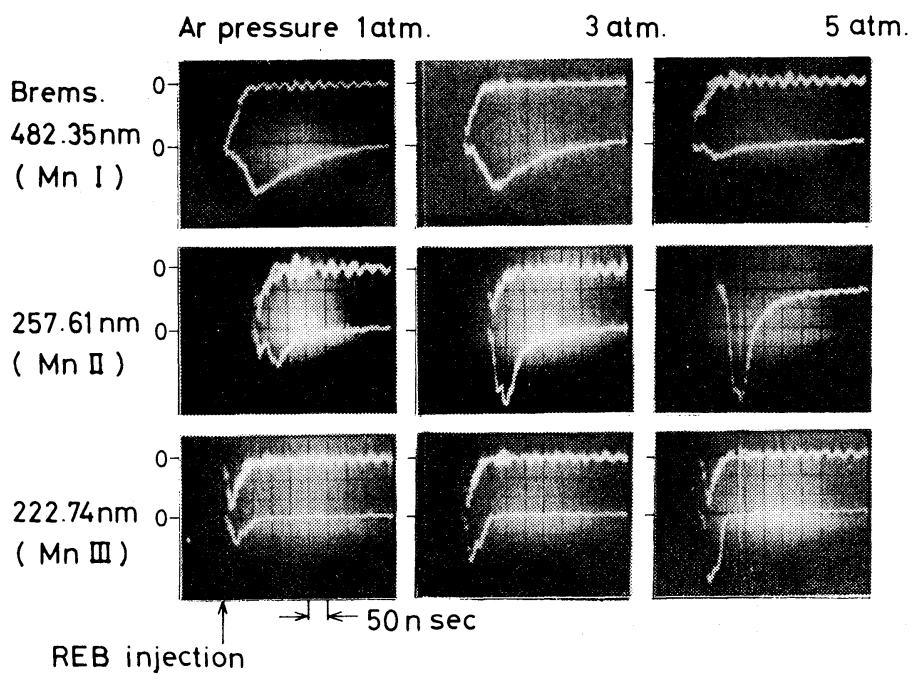

Fig. I1.REB 励起された緩衝気体中の Mn の各イオン化状態からの 発光波形。482.35 nm (Mn I ), 257.6I nm (Mn II), $222.74 \mathrm{~nm}$ ( $M n$ III)。

Time evolution of the REB pulse (Brems strahlung $X$-ray signal) and the spactral emission from the multiple ionization state of $\mathrm{Mn}$.

状態の Ar からのエネルギー移行によって励起されてスペクトルが発光し始めるのである。

次に, Mnの各スペクトルの発光強度の最大值の, 緩衝気体の圧力に対する依存性を, Fig. $12,13,14$ に示す。これらの実験結果は, Mn イオンの発光強度は, 緩衝気体が $\mathrm{Ar}, \mathrm{He}$ のいずれの場合にも, 圧力の 増加とともに強くなり飽和する傾向があることを示している。中性 $\mathrm{Mn}$ のスペクトルの発光強度は, 緩衝気 体が $\mathrm{Ar}$ の場合には 1 気圧以下の圧力において最大値を示し，圧力の増加とともに減少する傾向を示す。 また, $\mathrm{He}$ の場合には 2 気圧付近で最大值を示す。このような傾向が現われるのは, 緩衝気体の圧力の増加に 伴なって REB のエネルギーの阻止能が増大するため, Mn の上準位への励起の効率が向上する効果と, 励起 された Mn が緩衝気体の原子との衝突によって減衰される効果が競合しあうことによる。また，発光強度は緩 衝気体として Ar を用いた場合の方が，Heの場合よりも強いことが明らかになった。これは，緩衝気体のREB に対する阻止能の大きさの違いにより，Ar の方がエネルギーの吸収効率が良く，Fig. 17(a)に示すエネルギー・ 遷位ダイアグラムによって明らかなように，He の励起準位の近傍に適当な Mnの準位が存在しないことによ るものである。特に, $222.74 \mathrm{~nm}$ の線スペクトルは緩衝気体が $\mathrm{Ar}$ の場合にのみ観測された。 


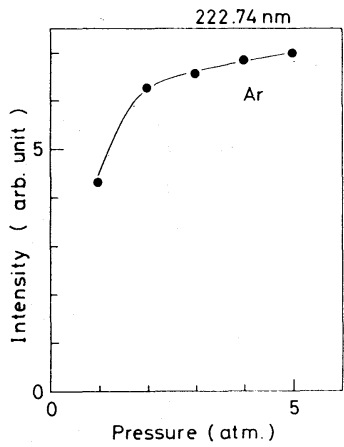

Fig. 12. 2 価の Mn イオン の発光強度の緩衝気 体の圧カに対する依 存性。

Variation of the intensity of the spectral emission from the two ionized $\mathrm{Mn}$ ion with the pressure of the buffer gas.

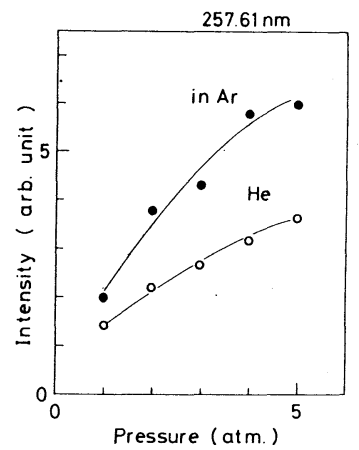

Fig. 13. 1 価の Mn イオン の発光強度の緩衝気 体の圧カに対する依 存性。

Variation of the intensity of the spectral emission from the singly ionized $\mathrm{Mn}$ ion with the pressure of the buffer gas

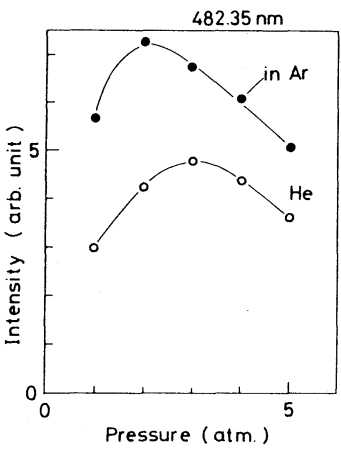

Fig. 14. 中性 Mn の発光強 度の緩衝気体の圧力 に対する依存性。 Variation of the intensity of the spectral emission from the neutral $\mathrm{Mn}$ with the pressure of the buffer gas.

\section{4 放電励起 $M n$ 化合物の発光特性}

緩衝気体として Ar および He を用いてレール電極間の放電励起による Mn 化合物の発光特性を REB 励 起の場合と比較した。

Fig. 15 に, 放電励起による, Mn 化合物の発光スペクトルが示されている。この実験では, 放電用電源の 初期充電電圧を $30 \mathrm{kV}$ ，緩衝気体の圧力は $\mathrm{Ar}$ ，He のいずれについても 1 気圧とした。短波長のスペクトル が主に観測された REB 励起と異なり，放電励起の場合には，長波長のスペクトルも観測され，特にレーザー 発振が報告されている MnI の $534.1 \mathrm{~nm}$ と $542.0 \mathrm{~nm}$ の発光が観測された。さらに, REB 励起の場合と異 なる特徴は, $\mathrm{C}_{2}$ の $516.5 \mathrm{~nm}, 385.2 \mathrm{~nm}, 360.7 \mathrm{~nm}$ のバンド・スペクトルや $250 \sim 290 \mathrm{~nm}$ の波長域にお いて $\mathrm{C}_{6} \mathrm{H}_{6}$ の特徵的なスペクトルが観測された。これらの分子は, 放電により化合物が解離した後に再結合 により生じたものであるが, 試薬が完全に解離してしまう REB 励起とは, かなり励起状態が異なっているも のと考元られる。Fig. 16 は, 比較的発光強度の強い線スペクトルの発光強度の時間変化を示している。これ らの波形を比較すると, MnI の $534.1 \mathrm{~nm}$ と, Mn II $257.6 \mathrm{~nm}$ の発光は, 放電電流の立ち上りと同時に 立ち上り，減衰とともに直ちに減衰している。これに対して，Mn Iの $482.35 \mathrm{~nm}$ と $534.1 \mathrm{~nm}$ の波形を比 較すると, $482.35 \mathrm{~nm}$ の波形は, 放電電流の減衰後も発光が長い間続いている。これは, 電流減衰後も, 高い エネルギー準位からの緩和により $482.35 \mathrm{~nm}$ の上準位が生成されていることを示している。これに対して， $534.1 \mathrm{~nm}$ の上準位は, 放電による直接励起だけが主な生成機構であり, 高エネルギー準位からの緩和による 生成は起らないものと考えられる。 REB 励起の実験では, $534.1 \mathrm{~nm}$ の発光はノイズ・レベル程度の信号しか 観測されず，このような低いエネルギー準位への直接励起や，高いエネルギー準位からの緩和による $534.1 \mathrm{~nm}$ の上準位の励起が非常に起り難いことを示しているものと考えられる。 
Discharge excitation

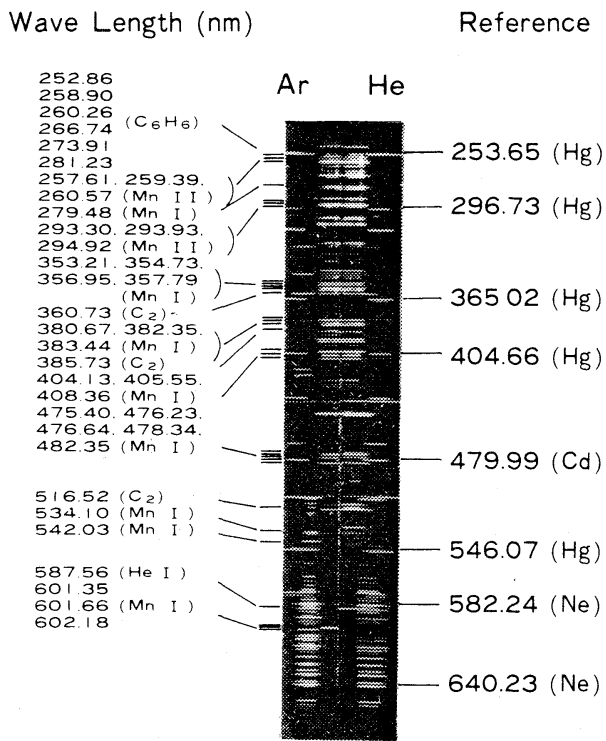

Fig. 15.レール電極間の放置によって励起された $\mathrm{Mn}$ 化合物の発光スペクトル。 $\mathrm{C}_{2}, \mathrm{C}_{6} \mathrm{H}_{6}$ などの分子スペクトルが観測された。

The emission spectrum for $\mathrm{CH}_{3} \mathrm{C}_{5} \mathrm{H}_{4}$ $\mathrm{Mn}(\mathrm{CO})_{3}$ and darrier gas mixture excited by the transverse arc discharge. The molecular spectra of $\mathrm{C}_{2}, \mathrm{C}_{6} \mathrm{H}_{6}$ as well as the atomic spectra of $\mathrm{Mn}$ were observed.

\section{Discharge excitation}

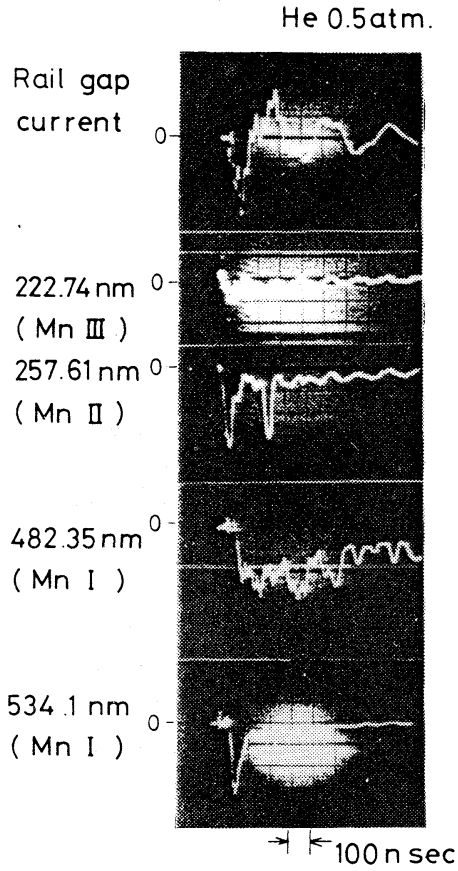

Fig. 16. 放電励起による $\mathrm{Mn}$ の発 光波形

The time evolution of the transverse discharge excitation of $\mathrm{Mn}$ and $\mathrm{He}$ mixture.

Fig. 17 に REB 励起と放電励起によって観測された Mnの発光スペクトルのエネルギー準位・遷位図が 示されている。例えば，REB 励起の場合には，上準位が $32 \mathrm{eV} の \mathrm{Mn}$ IIIの $222.74 \mathrm{~nm}$ の発光が観測され， この励起方法は，高エネルギー準位の励起に適し，短波長域の光源開発用に適した方法であると思われる。こ れに対して, 放電励起の場合, 高いエネルギー準位はあまり励起されず, 中性 $\mathrm{Mn}$ の低いエネルギー準位が広 範囲に励起されている。

\section{4. 結 論}

相対論的電子ビーム (REB) 励起レーザー実験用光学セルを試作し, 電子ビーム直接励起型レーザーの 1 例 として $\mathrm{Ar}-\mathrm{N}_{2}$ エネルギー移行型レーザー媒質の励起実験を行なった。さらに，高出力レーザーの可能性を 有するエネルギー移行型金属蒸気レーザーの基礎実験として，Mn 化合物蒸気を含んだ高気圧の緩衝気体中に $\mathrm{REB}$ を入射し, 電子ビームの伝搬特性, Mn の発光特性を調ベ, アーク放電で励起した場合と比較し, 励起 特性の違いを明らかにした。REB 励起は，高気圧の緩衝気体中に拡散された金属原子の高いエネルギー準位 
a)

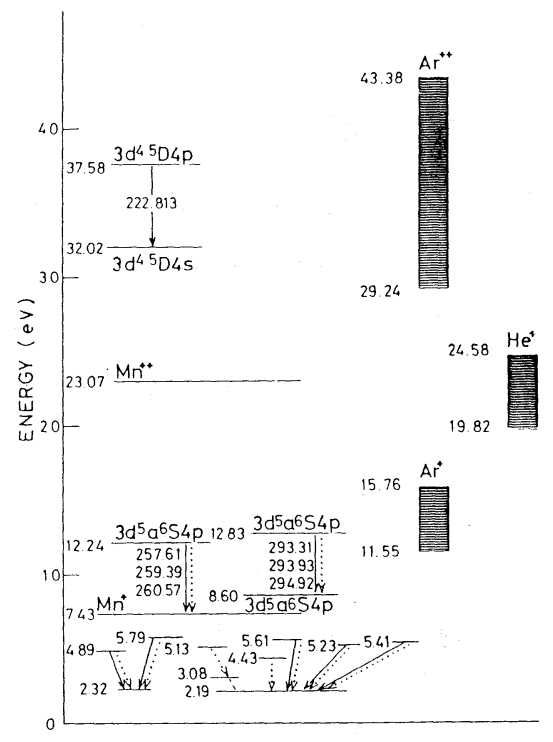

a) 高エネルギー領域，

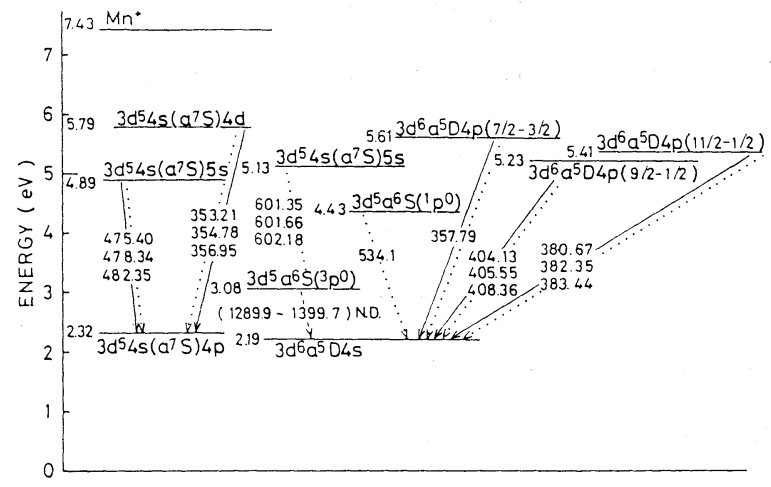

b）低エネルギー領域

Fig. 17. REB 励起および放電励起によって観測された Mn のスペクトル エネルギー・遷移ダイアグラム。

The energy-transition diagram corresponding to the observed spectral emission of $\mathrm{Mn}$.

a ; High energy region, b ; Low energy region.

The spectral emission from the high energy level, $\mathrm{Mn}$ III, $222.74 \mathrm{~nm}$, $32 \mathrm{eV}$, was typically observed by REB excitation. Mn I , 534.I nm was observed by the transverse arc discharge excitation. 


\section{核融合研究 第 52 巻第 4 号 1984 年 10 月}

の励起に適しているため，REB による直接励起や，準安定状態に励起された緩衝気体の原子からのエネルギー 移行によるレーザー準位の選択的励起は，短波長領域のエネルギー移行型金属蒸気レーザーを開発するうえで, 有効な手段であるものと考えられる。

\section{謝辞}

本研究の遂行にあたり，御指導および有益な討論をいただいた，山梨大学工学部 菅ノ又 伸次教授，なら びに桜井 彪 教授に感謝します。相対論的電子ビーム発生装置 YES-2 の製作にあたり御指導いただいた 松野 幸松技官, ならびに装置製作と実験の遂行に熱心に協力された大津 孝佳氏，山口 和也氏に感謝します。

この研究は, 昭和 58 年度文部省科学研究費, エネルギー特別研究（核融合）の援助によって行なわれた。

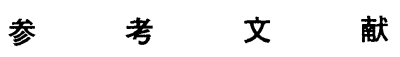

1) M. Pilch, W. T. Walter, N. Solimene, G. Gould and W. R. Bennett, Jr. : Appl. Phys. Lett., 7 (1965) 309.

2) Che Jhe Chen : Appl. Phys. Lett., 24 (1974) 499.

3) H. Matsuzawa and H. Kanai : Rev. Sci. Instrum., 54 (1983) 508 .

4) H. Matsuzawa : J. Vac. Sci. Technol., A 1 (1983) 1880.

5) NITTO RADCOLOR FILM 資料, 日東電気工業株式会社.

6) S. K. Searles and G. A. Hart : Appl. Phys. Lett., 25 (1974) 79 .

7) S. K. Searles : Appl. Phys. Lett., 25 (1974) 735.

8) W. E. Ernst, F. K. Tittle, W. L. Wilson and G. Marowsky : J. Appl. Phys., 50 (1979) 3879 . 